\title{
An Analytical Tool for Constructing and Evaluating Testing Strategic for COVID-19
}

Richard Kouri

North Carolina State University Poole College of Management

Donald Warsing

North Carolina State University Poole College of Management

Nikhil Singh

North Carolina State University Poole College of Management

Beena Thomas

North Carolina State University Poole College of Management

Robert B Handfield ( $\square$ roberthandfield@ncsu.edu )

North Carolina State University https://orcid.org/0000-0003-3895-1955

\section{Research}

Keywords: COVID-19, mathematical model, testing tool, cost-benefit analysis

Posted Date: October 5th, 2021

DOI: https://doi.org/10.21203/rs.3.rs-812275/v1

License: (9) This work is licensed under a Creative Commons Attribution 4.0 International License. Read Full License 


\section{Abstract \\ Background}

This paper describes the utilization of a mathematical modeling tool for evaluating alternative testing cadences for the SARS-CoV-2 virus that are applicable to any well-contained congregate setting. These settings include long-term care facilities, and public-school systems.

\section{Results}

Variables analyzed include population sizes, contagion factor, and unique testing objectives that congregate settings might have (e.g., differing susceptibilities, or varying underlying health conditions). The tool helps evaluate cost vs benefit for a range of testing cadences (e.g., daily, every 2 days, every 3 days, every week, every 2 weeks every 3 weeks and every 4 weeks) based on use of a commercially available antigen testing kit that costs $\$ 5$ per test.

\section{Conclusions}

Critical parameters derived as output of the model include total persons tested, average number in quarantine, average percent positives in quarantine, total testing cost, total infections allowed, cases averted, and cost per case averted. These parameters allow public health officials, site managers and/or on-site healthcare workers to optimize testing plans to align with available resources and support fact-based decision making. We also discuss how this tool can work with vaccine roll-out both in the United States and elsewhere.

\section{Background}

A key lesson learned from the COVID-19 pandemic is that a substantial increase in the rate of testing has the potential to mitigate the impact and potential reemergence of the pandemic, and its associated toll on humanity. An inability to test the population rapidly and effectively obscures the true scope of the pandemic, prevents an effective coordinated response, results in tremendous loss of life, and significantly impacts economic activity. In June 2020 , the U.S. House Energy \& Commerce Subcommittee chairman Diana DeGette stated, "If we're going to give the American public confidence so they can resume familiar activities and safely return to work, we need to expand testing to more people, including asymptomatic people [ $\left.{ }^{1}\right]$. Today in August 2021 , as the number of COVID cases from the Delta and Lambda [ $\left.{ }^{2}\right]$ variants escalate, test kits are again anticipated to be in short supply as demand for testing surges.

In July 2020, the Rockefeller Foundation $\left[^{3}\right]$ pointed out that $\$ 50 \mathrm{~B}$ to $\$ 75 \mathrm{~B}$ would be needed to carry out such testing in the U.S. It is important, however, to delineate carefully the nature of testing for viral infections in a pandemic, particularly to distinguish between screening testing, diagnostic testing, and surveillance testing $\left[{ }^{4}\right]$. Screening testing is intended to identify infected people who are asymptomatic and do not have known, suspected, or reported exposure to SARS-CoV-2. Diagnostic testing is intended to identify accurately any currently infected patients when those individuals have symptoms consistent with COVID-19, or when that person is asymptomatic but knows they have recently been exposed to SARS-CoV-2. Public health surveillance is the ongoing, systematic collection, analysis, and interpretation of health-related data essential to planning, implementation, and evaluation of public health reporting. Surveillance testing is performed on de-identified specimens, and thus, results cannot be used for individual decision-making.

Screening testing of asymptomatic individuals to detect people who are likely infectious has been critically underused in the COVID-19 pandemic, yet it is one of the most promising tools to combat the pandemic [5]. Successful population screening for SARS-CoV-2 depends on understanding both the spread of the virus between individuals and the spread within the body of a given individual.

SARS-CoV-2 can spread from individuals who are pre-symptomatic, symptomatic, or asymptomatic $\left[{ }^{6}, 7,8\right]$. Therefore, diagnosis and isolation based on symptoms alone will not help control the spread of the virus $\left[{ }^{9}, 10,{ }^{11}\right]$, primarily because in the early stages of the COVID-19 pandemic, approximately $59 \%$ of the spread of the virus results from pre-symptomatic or asymptomatic individuals [ ${ }^{12}$ ]. In addition, asymptomatic patients make up roughly $80 \%$ of infected individuals, and the viral loads of these asymptomatic patients are like those of symptomatic patients [ $\left.{ }^{13}\right]$. Further, children can harbor high levels of SARSCoV-2, but rarely are symptomatic or express severe disease $\left.{ }^{[14}\right]$. Recent information suggests that this is true even for the Delta variant $\left[{ }^{15}\right]$. For this reason, it is critical that asymptomatic individuals be tested as part of a comprehensive testing strategy.

The average level of contagion of the wild-type virus, or $\mathrm{R}_{0}$, was approximately $\left.2.3^{{ }^{16}}\right]$. The $\mathrm{R}_{0}$ parameter represents, on average, how many people an infected person can infect. For this study we used $\mathrm{R}_{0}$ values of less than 3 , which corelates to pandemic values for 2020 . Current data, however, shows that the value of $\mathrm{R}_{0}$ for mutated variants of the SARs-CoV-2 virus can range from 2.7 to 7 or even higher, as is being seen in the delta variant that is creating havoc now $\left[{ }^{17}, 18,{ }^{19}\right]$. Wearing a mask and social distancing have shown to decrease the value of $R_{0}$ to $1.0-1.5$ [16].

The spread of the SARS-CoV-2 virus was seen to be highly clustered and follow the "the law of vital few" or the $80 / 20$ rule [20]. Approximately $20 \%$ of the infected cases were observed to be responsible for $80 \%$ of all new cases, and $\sim 69 \%$ of infected individuals do not transmit the SARS-CoV- 2 virus to anyone else $\left[{ }^{21}\right]$. Identification and isolation of the few potential "superspreaders" is thus of critical importance to control the spread of the virus.

Confirmation that symptomatic individuals are infected by the SARS-CoV-2 virus is done most accurately by using nucleic acid-based tests such as qPCR [22]. These tests, however, are quite expensive ( $\$ 100)$, require special laboratory resources, and have sample-collection-to-results times of 24-48 hours. 
Alternative formats for nucleic-acid testing such as isothermal amplification, or use of CRISPR are available, but these tests are also expensive ( \$50) and require special laboratory resources $\left[{ }^{23},{ }^{24}\right]$.

Serologic testing indicates the presence of SARS-CoV-2 antibodies. These antibodies signify the existence of prior infections but cannot be used to establish the presence or absence of acute SARS-CoV-2 infection [ ${ }^{25}$.

On the other hand, tests for viral antigens are inexpensive $(\sim 5)$ and provide results in 30 minutes or less, but they do suffer from low analytical sensitivity (i.e., they require greater amounts of viral material to register a positive detection of COVID-19) $\left[5,{ }^{26},{ }^{27}\right]$. This lack of high sensitivity was one of the reasons that prevented the antigen test kits from being extensively used for testing at the outset of the COVID-19 pandemic. However, the lower sensitivity of the results obtained with the antigen test kits can be overcome by increasing the frequency of testing [11].

Considering the aforementioned factors, we chose the BinaxNOW antigen test kit from Abbott Laboratories for calculations in our analytic tool that is delineated below. Its requisite specificity (i.e., low levels of false positives), sensitivity (i.e., low levels of false negatives), rapid response ( 15 minutes), and low cost $(\sim 5)$ makes it a useful screening test in public settings for the SARS-CoV-2 virus $\left[{ }^{28},{ }^{29}\right]$. Importantly, these kits are easy-to-use and are being produced by Abbott at a rate of roughly 50 million tests per month [30]. They are also commercially available in retail pharmacies but the price of an individual test at a pharmacy is higher $(\sim 25)$ than the price of bulk-packed tests that would be procured for ongoing screening $\left.{ }^{31}\right]$. Two important additional features of these kits are first that each test card contains an RFID code that can be used to support the digitization of the tests results, and second, the antibodies used on the test card to detect the presence of SARS-CoV-2 are directed at the nucleocapsid proteins, not the spike proteins. Thus, this antigen test should effectively detect the known variants of SARS-CoV-2 [ $\left.{ }^{32}\right]$.

In this paper, we have updated and adapted the analytical model proposed by Paltiel et al. $\left[{ }^{33}\right]$ to evaluate the costs and timing required to re-open any wellcontained congregate setting using the BinaxNOW antigen test kits. These settings include those already determined to be "hot-spots" for virus spread such as schools, long-term care facilities, food-processing centers, and correctional facilities. The Paltiel et al. model [33] is based on the SEIR mathematical modeling of infectious disease, and as such is applicable to any infectious disease, including COVID-19.

\section{Results}

A meta-analysis comparing the clinical study results of symptoms, results of nucleic acid tests with those of the BinaxNow antigen test is summarized in Table 1. Columns 1-5 of Table 1 show the typical daily rates of viral growth in the nasal passages of individuals infected with the SARS-CoV-2 virus (as measured by qPCR), the level of symptomology, and the probability of disease transmission during these time intervals.

In the qPCR tests, the virus is detectable in nasal swabs as soon as 1.5 to 2 days post infection remains detectable for many days, and usually wanes to undetectable levels by 2 weeks after infection. The nucleic acid assay is, therefore, not necessarily effective as a screening test for infectious virus because the assay can also detect the presence of viral RNA (not necessarily intact viruses), which implies that for certain infected individuals the nucleic acid test will be positive for weeks (if not months) after infection [ $\left.{ }^{34}, 35\right]$. Moreover, the results of the nucleic acid test are usually communicated back to the user 24 to 48 hours after the swab sample is taken. Thus, decisions based on nucleic acid tests are effectively displaced by 24 to 48 hours from the data shown in Column 5 of Table 1. The typical pattern of viral load in an infected individual as measured by the BinaxNOW antigen test is presented in column 6 of Table 1 . These data were adapted from Perchetti et al. [28] and James et al. [ ${ }^{36}$ ]. This antigen test is not as sensitive as nucleic acid tests for detecting the extremely low viral loads present at the early onset of a SARS-CoV-2 infection. The likely limit of detection of this antigen test is about 100 times less than the qPCR tests $(\sim 10 \mathrm{E} 5 \mathrm{cp} / \mathrm{ml})$. Perchetti et al. [28] have shown that the BinaxNOW card has an analytical sensitivity approximately equivalent to a generic qPCR cycle threshold value of 29 to 30 . This antigen test, however, does appear to detect the virus in what could be described as the "Goldilocks" zone, which is the period when an infected individual is most likely to be infectious (i.e., 4-7 days post infection; see Table 1, column 3). Also noteworthy is that antigen tests revert to identification of weak or negative results once the individual's immune system is actively killing the virus and the risk of transmission is low. The analytic specificity of the BinaxNOW card exceeds $98 \%[36,28]$.

Different laboratories have determined the level of sensitivity of the BinaxNOW test, and results vary from $52 \%$ for asymptomatic persons (83\% for symptomatic persons) [36] to $96.5 \%$ (95\% confidence interval 90.0\% - 99.3\%) [29]. As shown by Paltiel et al. [33] and Larremore et al. [11], the level of false negatives can be limited by testing at frequent intervals - that is, daily, every 2 days, or every 3 days.

To conduct our analysis, we customized the publicly available computer code $\left[{ }^{39}\right]$ in the R programming language that was originally written to implement the SEIR model of Paltiel et al. [33] Our customization of this code allowed us to expand the output parameters and to examine the costs and benefits of varying specific epidemic parameters or changing specific attributes with respect to testing. For the data presented in this paper, we used a given set of parameters that remained invariant, and then tested the impact of different test cadences, different $\mathrm{R}_{0}$ values, and different population sizes on the costs and benefits of these testing cadences. The parameters that we kept as invariant in the tool for our calculations were as follows.

1. Number of times per day testing will be done: 1

2. Number of days per week: 5

3. Days of incubation:3 $\left[{ }^{40}, 16\right]$

4. Time to recovery: 10 days $\left[{ }^{41}\right]$

5. Percent asymptomatic advancing to symptoms: $30 \%[42,43,44]$

6. Test sensitivity: $80 \%[36,29,28]$ 
7. Test specificity: $98 \%[36,28]$

8. Antigen test kit cost: $\$ 5.00[30]$

9. Testing horizon: 80 days

An important additional parameter is that the model allows for "exogenous shocks." That is, it allows the introduction of infections to the population at prescribed intervals and of prescribed size. Unless otherwise noted, we allowed 10 new infections per week into the test populations. Detailed below are results of modeling using the tool we developed for four different scenarios that are easily obtained by simply adjusting the different parameters in the tool.

Assumptions for carrying out these tests are as follows. All individuals who test positive will be retested, and if they retest positive, they will be sent home for quarantine for 10 days. We define these individuals as true positives. Individuals who retest negative will be allowed to resume normal activities. They are assumed to be false positives. True positives after quarantine return to normal activities and are not tested again. False positives will remain in the "susceptible" pool and tested according to the scheduled cadence.

Scenario 1: The results of testing a population of 30,000 individuals using three different test cadences is shown in Table 2 . This population size is typical of the total student and staff population of the public school system in a mid-sized county in the United States. The three test cadences examined using the antigen test kit were as follows: 1) daily testing for a given time (i.e., 1 to 15 weeks) followed by a second test regimen of testing every 4 weeks for the remainder of a 16-week test horizon, 2) testing every 2 days for a given period of weeks followed by every 4 weeks, and 3 ) testing every 3 days for a given period of weeks followed by every 4 weeks. The model is flexible and allows the user to compare test cadences of daily, every 2 days, every 3 days, weekly, every 2 weeks, every 3 weeks, and every 4 weeks.

The results in Table 2 shown in bold font highlight the test conditions that resulted in the best outcomes from combinations of the above cadences in terms of low cost, low numbers of people in quarantine, large numbers of infections prevented, and the lowest costs per case averted. The best outcome occurs around weeks 4 to 6 of daily testing followed by every 4-week testing, or around weeks 6 to 8 of every 2 day testing (followed by 4 -week testing), or around weeks 9 to 11 of every 3 day testing (followed by every 4-week testing). Comparing the three test cadences shows that primary testing daily would be the most expensive approach both in terms of total cost $(\sim 4.0 \mathrm{M})$ and cost per case averted $(\sim 170)$. The lowest cost alternative is the cadence that uses every 3-day initial testing followed by every 4 -week testing. This approach saves about $\$ 300 \mathrm{~K}$ relative to the every-2-day cadence, and about $\$ 1.5 \mathrm{M}$ relative to the daily cadence. These results demonstrate the value of this modeling approach in providing policymakers with an analytical means of comparing different potential testing scenarios to determine the most efficacious outcomes for the circumstances or available resources.

Scenario 2: A comparison of output using three different $\mathrm{R}_{0}$ values in the model is summarized in Table 3 . The table shows only those ranges of testing cadences that resulted in the best outcomes in terms of low cost, low numbers of people in quarantine, large numbers of infections prevented, and the lowest costs per case averted. An $R_{0}$ of 2.3 was chosen because it represents the wild-type strain of SARS-CoV-2 that has been prevalent in the U.S. [16]. The $\mathrm{R}_{0}$ of 3.0 was chosen for comparison because some variants (e.g., the Alpha variant) have an $R_{0}$ that is bigger by a factor of 0.3 to 0.7 [18]. The $R_{0}$ value of 1.5 was chosen because this is the rate of spread observed when the population in consideration actively wears masks, practices social distancing, and maintains hand hygiene [16]

According to the data in Table 3, good hygiene would save approximately $\$ 400 \mathrm{~K}$ in testing costs (i.e., compare $R_{0} 2.3$ to $R_{0} 1.5$ ). If a new variant has an $R_{0}$ of 3.0 , however, the cadence of testing every 3 days followed by testing every 4 weeks is never able to decrease infections below $45 \%$ of the tested population. Remember that in this model, we are allowing new infections to enter this population at rate of 10 new cases per week. In this scenario, one would have to increase the rate of primary testing to every 2 days to see a decrease in new cases to below $20 \%$ of the tested population (see Table 3 ). The every-2-day regimen for a period of 10-12 weeks reduces the infection rate to below $20 \%$ at a cost of roughly $\$ 4 \mathrm{M}$. Unfortunately, variants with $\mathrm{R}_{0}$ in the range of $4-7$ already have been identified $[17,19,45,46]$. We also tested an R0 of 6 in our model using the same conditions stated for Table 3 , and the only testing cadence that impacted the degree of infection significantly (i.e., 79\% of cases averted) was daily testing. The cost of this daily testing schedule was $\$ 9,835,355$. Clearly, variants with an $\mathrm{R}_{0}$ greater than 3.0 will be very expensive to manage.

Scenario 3: To determine if our model is capable of being scaled-up to handle testing of larger populations, we evaluated the same testing strategy employed above (i.e., primary screen of daily, every 2 day, or every 3 days, followed by a secondary screening of every 4 weeks) for population sizes of ten thousand, one hundred thousand, and 1 million people, respectively (Table 4). For ease of comparison, only those ranges of test cadences that produced the best outcomes are presented. The best test outcomes occurred at different times based on the size of the population being tested. For example, in comparing the cost per case averted across the three different population sets, the best test cadence consisted of primary testing every 3 days for a given period followed by secondary testing every 4 weeks (see Table 4). Also note that the times for primary testing that resulted in the best outcomes seemed to be 10 to 12 weeks for the 10,000 population, 8 to 10 weeks for the 100,000 population, and 7 to 9 weeks for the 1,000,000 population. Thus, the model helps provide flexible, actionable intelligence regardless of the size of the population being tested.

Scenario 4: In another set of experiments, we considered testing strategies for a typical long-term-care facility. Output of the model for these cases is detailed in Table 5. The size of the population tested in this facility was assumed to be 100 considering both the patients and staff. Criteria for a successful testing strategy are unique to these types of facilities. For example, a large percentage of the patients in long-term-care facilities likely have significant underlying health conditions, and therefore keeping the number of infections to a minimum is a high priority. Moreover, since visitor access to these facilities is restricted, this reduces the possibility of asymptomatic but infected individuals carrying the virus into the facilities. Our computations for long-term care facilities employed the following test parameters: two new outside infections into the facility every four weeks, $R_{0}$ of 1.5 (as increased safety protocols are more likely), and a mortality level of infections of $8 \%\left[{ }^{47}\right]$. Results in Table 5 show that daily testing for 15 weeks still resulted in approximately $10 \%$ of the 
individuals at a typical long-term care center becoming infected; and testing resulted in a cost of approximately $\$ 30,000$. Testing regimens of every 2 days or every 3 days resulted in $11 \%-15 \%$ of the individuals becoming infected while the costs for these testing regimens were approximately $\$ 16,000$ and $\$ 11,000$, respectively. Even though the mortality rate for these nursing home settings was parameterized at $8 \%$, this higher mortality rate did change the percent infection rate, or the cost of testing. We conclude that this model helps provide information for fact-based decisions on testing in long-term-care facilities.

\section{Conclusions}

It is our view that the U.S. has failed to develop an appropriate national testing strategy, and policy makers have failed to develop a national roadmap for doing so. As COVID variants grow, testing is re-emerging as a critical element to combating the spread of the pandemic. Lacking Federal guidance, states and local governments have been forced to author their own plans for testing. This is especially challenging, because the public health information can be confusing, and testing policies often transcend the jurisdiction or expertise of local or state agencies (e.g., the availability of resources for testing, vaccines, therapeutics, personal protection, assessing the risk of novel viral variants, assessing the long-term health consequences of COVID-19, among other issues). For example, in early 2021 in the U.S., several pathways for reopening schools were proposed $\left[{ }^{48}, 49,50\right]$, but the costs, resources and management infrastructure required for adopting such regimens were fragmented or unavailable at the time. The U.S. has no clear methodology for establishing an endpoint metric such as testing positivity rates or level of infections per 100,000 individuals. Moreover, the CDC defines test positivity rates based solely on nucleic acid amplification test results $\left[{ }^{51}\right]$, which, in the early days of the COVID-19 pandemic were being collected mostly from symptomatic individuals. The CDC admits that high positivity results can be misleading because mostly those at greatest risk of infection within a community are being tested. Moreover, certain jurisdictions prioritize data collection for positive test results over negative results. In fact, there is little consistency in how states define, publish, and present COVID-19 data. One of the major aggregators of U.S. COVID-19 data from the earliest days of the pandemic, "The COVID Tracking Project", eventually stopped tracking COVID-19 positivity rates, in part because of these data inconsistencies $\left[{ }^{52}\right]$.

The availability of vaccines has mitigated somewhat, but not eliminated, the need for large scale testing in the US. As of July 2021, data from the CDC [ ${ }^{53}$ ] show that $48 \%$ of total US population is fully vaccinated, however, five states have less than $35 \%$ of their populations fully vaccinated. The rate of vaccination has slowed considerably, and vaccine hesitancy is the major cause of this slow down. The rapid rise of the Delta variant in the US might curb some of this hesitancy. The availability of the tool described in this paper suggests a strategy for managing COVID-19 in both vulnerable and vaccinehesitant populations. The individuals hesitant to be vaccinated and who are part of congregant settings within these areas (e.g., schools, work facilities, and hospitals) would be tested routinely and allowed to return to school or work if negative and placed in quarantine if positive. This approach could also limit the spread of infection in those countries where low levels of vaccination have resulted from resource limitations. It has been estimated that vaccines will not be available to many of the poorest nations until, at least, $2023\left[{ }^{54}\right]$.

The availability of simplified analytic modeling tools that can help decision makers determine when and how to reopen certain congregate settings, like schools, is an absolute necessity. In this research, we offer a strategic analytic tool for utilization of low-cost antigen tests in a comprehensive, targeted testing strategy, which - in our perspective as academics specializing in business and biotechnology management - is critical and allows for effective use of the various planning and execution protocols. Furthermore, strategic deployments have the potential to improve dramatically the production, procurement, and distribution of test kits, and can be of critical help to control and mitigate the spread of the SARS-CoV-2 virus in the U.S., and around the globe.

\section{Declarations}

Ethics approval/Consent for publication: There were no human subjects employed in this study.

Availability of data and materials: Results were generated using the computational tool available at https://nsingh23.shinyapps.io/NCSUDeliverablesTestingVer/. The tool produces both summary results and detailed output at the request of the user. Only summary results appear in this manuscript.

Competing Interests: The authors declare that they have no competing interests.

Funding: Supported in part by NIIMBL COVID19-1.03

Authors' contributions: Kouri: Conceptualization, Methodology, Writing; Warsing: Writing, Reviewing, Editing; Singh: Visualization, Data Modeling; Thomas, : Validation, Manuscript Review and Editing; Handfield: Validation, Writing, Reviewing Editing.

Acknowledgements: Not applicable

\section{References}

1. Frieden J. COVID-19 Testing supplies still needed, lawmakers told. In: Medpage Today. 2020.

https://www.medpagetoday.com/infectiousdisease/covid19/86842. Accessed 2 June 2020

2. Haseltine WA. It Is Time To Pay Close Attention To The Lambda Variant Now Devastating South America. 2021. https://www.forbes.com/sites/williamhaseltine/2021/08/10/it-is-time-to-pay-close-attention-to-the-lambda-variant-now-devastating-south-america/? sh=e43777a4348e. Accessed 12 Aug 2021

3. National COVID-19 testing \& tracing action plan. In: rockefellerfoundation.org. 2020. https://www.rockefellerfoundation.org/national-covid-19-testingand-tracing-action-plan/. Accessed 20 May 2020

Page 5/16 
4. Testing Strategies for SARS-CoV-2. In: Centers for Disease Control and Prevention. 2021. https://www.cdc.gov/coronavirus/2019ncov/lab/resources/sars-cov2-testing-strategies.html. Accessed 04 Aug 2021

5. Mina MJ, Parker R, Larremore DB. Rethinking Covid-19 Test Sensitivity - A Strategy for Containment. N Engl J Med. 2020;doi:10.1056/NEJMp2025631.

6. Arons MM, Hatfield KM, Reddy SC, et al. Presymptomatic SARS-CoV-2 Infections and Transmission in a Skilled Nursing Facility. N Engl J Med 2020;382:2081-90.

7. Sutton D, Fuchs K, D'Alton M, Goffman D. Universal Screening for SARS-CoV-2 in Women Admitted for Delivery. N Engl J Med. 2020;382:2163-4.

8. Oran DP, Topol EJ. Prevalence of Asymptomatic SARS-CoV-2 Infection: A Narrative Review. Ann Intern Med. 2020;173:362-7.

9. Moghadas SM, Fitzpatrick MC, Sah P, et al. The implications of silent transmission for the control of COVID-19 outbreaks. Proc Natl Acad Sci USA. 2020;117:17513-5.

10. Grassly NC, Pons-Salort M, Parker EPK, et al. Comparison of molecular testing strategies for COVID-19 control: a mathematical modelling study. Lancet Infect Dis. 2020;doi:https://doi.org/10.1016/S1473-3099(20)30630-7.

11. Larremore DB, Wilder B, Lester E, et al. Test sensitivity is secondary to frequency and turnaround time for COVID-19 screening. Sci Adv. $2021 ; 7$ :eabd5393.

12. Johansson MA, Quandelacy TM, Kada S, et al. SARS-CoV-2 Transmission From People Without COVID-19 Symptoms. JAMA Netw Open. 2021;4:e2035057.

13. Tan J, Liu S, Zhuang L, et al. Transmission and clinical characteristics of asymptomatic patients with SARS-CoV-2 infection. Future Virol. 2020; doi:10.2217/fvl-2020-0087.

14. Information for Pediatric Healthcare Providers. In: Centers for Disease Control and Prevention, 2020. https://www.cdc.gov//coronavirus/2019ncov/hcp/pediatric-hcp.html. Accessed 30 Dec 2020

15. The Delta Variant and Children: How Concerned Should Parents Be? In: Cleveland Clinic, Health Essentials. 2021. https://health.clevelandclinic.org/deltavariant-and-children/. Accessed 5 Aug 2021

16. Li T, Liu Y, Li M, et al. Mask or no mask for COVID-19: A public health and market study. PLOS ONE. 2020;15:e0237691.

17. Burki TK. Lifting of COVID-19 restrictions in the UK and the Delta variant. Lancet. 2021;doi:https://doi.org/10.1016/S2213-2600(21)00328-3.

18. Volz E, Mishra S, Chand M et al. Assessing transmissibility of SARS-CoV-2 lineage B.1.1.7 in England. medRxiv. 2020;doi:https://www.medrxiv.org/content/10.1101/2020.12.30.20249034v2.

19. Li B, Deng A, Li K, et al. Viral infection and transmission in a large, well-traced outbreak caused by the SARS-CoV-2 Delta variant. medRxiv. 2021;doi:https://doi.org/10.1101/2021.07.07.21260122.

20. Tufekci Z. This Overlooked Variable Is the Key to the Pandemic It's not R. In: The Atlantic. 2020. https://www.theatlantic.com/health/archive/2020/09/koverlooked-variable-driving-pandemic/616548/. Accessed 1 Oct 2020

21. Adam DC, Wu P, Wong JY, Lau EHY, et al. Clustering and superspreading potential of SARS-CoV-2 infections in Hong Kong. Nat Med. 2020;26:1714-9.

22. Vogels CBF, Brito AF, Wyllie AL, et al. Analytical sensitivity and efficiency comparisons of SARS-COV-2 qRT-PCR primer-probe sets. medRxiv. 2020;doi:10.1101/2020.03.30.20048108

23. Thi VLD, Herbst K, Boerner K, et al. A colorimetric RT-LAMP assay and LAMP-sequencing for detecting SARS-CoV-2 RNA in clinical samples. Sci Transl Med. 2020;12:eabc7075.

24. Broughton JP, Deng X, Yu G, et al. CRISPR-Cas12-based detection of SARS-CoV-2. Nature Biotechnol. 2020;38:870-4.

25. Interim Guidelines for COVID-19 Antibody Testing. In: Centers for Disease Control and Prevention. 2019. https://www.cdc.gov/coronavirus/2019ncov/lab/resources/antibody-tests-guidelines.html

26. Mina MJ, Anderson KG. COVID-19 testing: One size does not fit all. Science. 2021;371:126-7.

27. Coronavirus (COVID-19) Update: FDA Informs Public About Possible Accuracy Concerns with Abbott ID NOW Point-of-Care Test. In: US Food \& Drug Administration. 2020. https://www.fda.gov/news-events/press-announcements/coronavirus-covid-19-update-fda-informs-public-about-possibleaccuracy-concerns-abbott-id-now-point. Accessed 14 May 2020

28. Perchetti GA, Huang ML, Mills MG, et al. Analytical Sensitivity of the Abbott BinaxNOW COVID-19 Ag Card. J Clin Microbiol. 2021;59:e02880-20.

29. Pollock NR, Jacobs JR, Tran K, et al. Performance and Implementation Evaluation of the Abbott BinaxNOW Rapid Antigen Test in a High-Throughput Drive-Through Community Testing Site in Massachusetts. J Clin Microbiol. 2021;59:e00083-21.

30. Abbott's fast, \$5, 15-minute, easy-to-use covid-19 antigen test receives FDA Emergency Use Authorization; Mobile App displays test results to help our return to daily life; ramping production to 50 million tests a month. In: ABBOTT Press Releases. 2020. https://abbott.mediaroom.com/2020-08-26Abbotts-Fast-5-15-Minute-Easy-to-Use-COVID-19-Antigen-Test-Receives-FDA-Emergency-Use-Authorization-Mobile-App-Displays-Test-Results-to-Help-OurReturn-to-Daily-Life-Ramping-Production-to-50-Million-Tests-a-Month. Accessed 26 Aug 2020

31. Cortez MF, Flanagan C, Fabian J. U.S. Buys Almost All Abbott's \$5 Rapid Tests Made This Year. 2020. https://www.bloomberg.com/news/articles/202008-26/abbott-gets-ok-on-5-15-minute-covid-test-that-avoids-lab-delay. Accessed 26 Aug 2020

32. Vann M. COVID-19 tests can spot variants, lab companies insist. In: ABC NEWS. 2021. https://abcnews.go.com/health/covid-19-test-spot-variants-labcompanies-insist/story?id=75756295. Accessed 10 Feb 2021

33. Paltiel AD, Zheng A, Walensky, RP. Assessment of SARS-CoV-2 screening strategies to permit the safe reopening of college campuses in the United States. JAMA Network Open.2020; 3(7):e2016818.

34. Larremore DB, Wilder B, Lester E, et al., Test sensitivity is secondary to frequency and turnaround time for COVID-19 surveillance. medRxiv. 2020; doi:https://doi.org/10.1101/2020.06.22.20136309 
35. Avanzato VA, Matson MJ, Seifert SN, et al. Case Study: Prolonged Infectious SARS-CoV-2 Shedding from an Asymptomatic Immunocompromised Individual with Cancer. Cell. 2020;183:1901-12.E9.

36. James AE, Gulley T, Kothari A, et al. Performance of the BinaxNOW coronavirus disease 2019 (COVID-19) Antigen Card test relative to the severe acute respiratory coronavirus virus 2 (SARS-CoV-2) real-time reverse transcriptase polymerase chain reaction (rRT-PCR) assay among symptomatic and asymptomatic healthcare employees. Infect Control \& Hosp Epidemiol. 2021;doi:10.1017/ice.2021.20.

37. Adapted from Goyal A, Reeves DB, Ojeda EFC, et al. Wrong person, place and time: viral load and contact network structure predict 5 SARS-CoV-2 transmission and super-spreading events. medRxiv. 2020;doi:10.1101/2020.08.07.20169920.

38. Courage KH. Rapid \$1 Covid-19 tests exist. Why can't we get them? In: Vox. 2020; https://www.vox.com/2020/8/27/21374002/rapid-covid-19-test-3mabbott. Accessed-27 Aug 2020

39. Aravamuthan S, Kent S. Paltiel-COVID-19-Screening-for-College-Secondary-Shock. In: Github. 2020. https://github.com/aravamu2/Paltiel-COVID-19Screening-for-College-Secondary-Shock/blob/master/calculations.Rmd. Accessed 10 Sep 2020

40. He X, Lau EHY, Wu P, et al. Temporal dynamics in viral shedding and transmissibility of COVID-19. Nat Med. 2020;26:672-5.

41. Interim Guidance on Ending Isolation and Precautions for Adults with COVID-19. In: Centers for Disease Control and Prevention. 2019. https://www.cdc.gov/coronavirus/2019-ncov/hcp/duration-isolation.html. Accessed Aug 2020

42. Day M. Covid-19: four fifths of cases are asymptomatic, China figures indicate. BMJ 2020;369:m1375.

43. Yang R, Gui X, Xiong Y. Comparison of Clinical Characteristics of Patients with Asymptomatic vs Symptomatic Coronavirus Disease 2019 in Wuhan, China. JAMA Netw Open. 2020;3:e2010182.

44. Ing AJ, Cocks C, Green JP. COVID-19: in the footsteps of Ernest Shackleton. Thorax. 2020;75:693-4.

45. Greaney AJ, Loes AN, Crawford KHD, et al. Comprehensive mapping of mutations to the SARS-CoV-2 receptor-binding domain that affect recognition by polyclonal human serum antibodies. bioRxiv. 2021;29:463-76.

46. Lewis T. How Dangerous Is the Delta Variant, and Will It Cause a COVID Surge in the U.S.? In: Scientific American. 2021;https://www.scientificamerican.com/article/how-dangerous-is-the-delta-variant-and-will-it-cause-a-covid-surge-in-the-u-s/. Accessed 29 Jun 2021

47. About $8 \%$ of people who live in US long-term-care facilities have died of COVID-19-nearly 1 in 12 . For nursing homes alone, the figure is nearly 1 in 10. In: The Covid Tracking Project. 2021;https://covidtracking.com/nursing-homes-long-term-care-facilities. Accessed 7 Mar 2021

48. Zimmerman KO, Akinboyo IC, Brookhart MA, et al. Incidence and Secondary Transmission of SARS-CoV-2 Infections in Schools. Pediatrics. 2021;147:e2020048090.

49. Losina E, Leifer V, Millham L, et al. College Campuses and COVID-19 Mitigation: Clinical and Economic Value. Ann Intern Med. 2021;174:472-83.

50. Falk A, Benda A, Falk P, et al. COVID-19 Cases and Transmission in 17 K-12 Schools - Wood County, Wisconsin, August 31-November 29, 2020. Morb Mortal Wkly Rep. 2021;70:136-40.

51. Calculating SARS-CoV-2 Laboratory Test Percent Positivity: CDC Methods and Considerations for Comparisons and Interpretation. In: Centers for Disease Control and Prevention. 2019. https://www.cdc.gov/coronavirus/2019-ncov/lab/resources/calculating-percent-positivity.html.

52. Simon S. Inconsistent reporting practices hampered our ability to analyze COVID-19 data. Here are three common problems we identified. In: The Covid Tracking Project. 2021. https://covidtracking.com/analysis-updates/three-covid-19-data-problems. Accessed 22 Jul 2021

53. COVID-19 Vaccinations in the United States. In Centers for Disease Control and Prevention. https://covid.cdc.gov/covid-data-tracker/\#vaccinations. Accessed 8 Jul 2021

54. Padma TV. COVID vaccines to reach poorest countries in 2023 - despite recent pledges. Nature. 2021;595:342-343.

\section{Tables}




\begin{tabular}{|c|c|c|c|c|c|}
\hline 1 & 2 & 3 & 4 & 5 & 6 \\
\hline Days of infection & $\begin{array}{l}\text { Viral load/ml } \\
{[37,38]}\end{array}$ & $\begin{array}{l}\text { Symptoms for } \\
\text { typical case }[11,38]\end{array}$ & $\begin{array}{l}\text { Transmission } \\
\text { probability }[11,38]\end{array}$ & Nucleic acid test [37] & Antigen test $[36,28]$ \\
\hline 1 & $1.00 \mathrm{E}+03$ & None & $0 \%$ & weak & Negative \\
\hline 2 & $1.00 \mathrm{E}+05$ & None & $<1 \%$ & weak to positive & Weak \\
\hline 3 & $1.00 \mathrm{E}+07$ & None & $10 \%$ & positive & weak to positive \\
\hline 4 & $1.00 \mathrm{E}+08$ & Weak & $40 \%$ & positive & Positive \\
\hline 5 & $1.00 \mathrm{E}+09$ & Weak & $80 \%$ & Positive & Positive \\
\hline 6 & $1.00 \mathrm{E}+08$ & Weak & $>80 \%$ & Positive & Positive \\
\hline 7 & $1.00 \mathrm{E}+07$ & Yes & $60 \%$ & Positive & Positive \\
\hline 8 & $1.00 \mathrm{E}+06$ & Yes & $50 \%$ & Positive & Positive \\
\hline 9 & $1.00 \mathrm{E}+05$ & Weak & $20 \%$ & Positive & weak \\
\hline 10 & $1.00 \mathrm{E}+05$ & Weak & $<10 \%$ & Positive & weak \\
\hline 11 & $1.00 \mathrm{E}+04$ & None & $<10 \%$ & Positive & Negative \\
\hline 12 & $1.00 \mathrm{E}+04$ & none & $<10 \%$ & Positive & Negative \\
\hline 13 & $1.00 \mathrm{E}+03$ & none & $<10 \%$ & weak to positive & Negative \\
\hline 14 & $1.00 \mathrm{E}+03$ & none & $<10 \%$ & weak to positive & negative \\
\hline 15 & $1.00 \mathrm{E}+03$ & none & $<10 \%$ & weak to positive & Negative \\
\hline 16 & $1.00 \mathrm{E}+02$ & none & $<10 \%$ & weak to positive & negative \\
\hline 17 & $1.00 \mathrm{E}+02$ & none & $<10 \%$ & weak to positive & negative \\
\hline 18 & $1.00 \mathrm{E}+01$ & none & $<10 \%$ & negative to weak & negative \\
\hline 19 & $1.00 \mathrm{E}+01$ & none & $<10 \%$ & negative to weak & negative \\
\hline 20 & $1.00 \mathrm{E}+01$ & none & $<10 \%$ & negative to weak & negative \\
\hline
\end{tabular}


Table 2. Comparison of three different primary test cadences and one secondary test cadence on 30,000 people

\begin{tabular}{|c|c|c|c|c|c|c|c|c|c|c|}
\hline $\begin{array}{l}\text { Cadence } \\
\text { of } \\
\text { Primary } \\
\text { Testing }\end{array}$ & $\begin{array}{l}\text { Weeks of } \\
\text { Primary } \\
\text { Testing }\end{array}$ & $\begin{array}{l}\text { Cadence of } \\
\text { Secondary } \\
\text { Testing }\end{array}$ & $\begin{array}{l}\text { Total } \\
\text { Persons } \\
\text { Tested }\end{array}$ & $\begin{array}{l}\text { Average } \\
\text { Number in } \\
\text { Quarantine }\end{array}$ & $\begin{array}{l}\text { Average \% } \\
\text { True Positives } \\
\text { in Quarantine }\end{array}$ & $\begin{array}{l}\text { Total } \\
\text { Testing } \\
\text { Cost }\end{array}$ & $\begin{array}{l}\text { Total } \\
\text { Infections }\end{array}$ & $\begin{array}{l}\text { Percent } \\
\text { Infected }\end{array}$ & $\begin{array}{l}\text { Cases } \\
\text { Averted }\end{array}$ & $\begin{array}{l}\text { Cost per } \\
\text { Case } \\
\text { Averted }\end{array}$ \\
\hline Daily & 1 & $\begin{array}{l}\text { Every } 4 \\
\text { Weeks }\end{array}$ & 225,000 & 1,379 & $96.7 \%$ & $\begin{array}{l}\$ \\
1,174,290\end{array}$ & 29,123 & $99 \%$ & 277 & $\$ 4,239$ \\
\hline Daily & 2 & $\begin{array}{l}\text { Every } 4 \\
\text { Weeks }\end{array}$ & 378,834 & 792 & $89.2 \%$ & $\begin{array}{l}\$ \\
1,947,280\end{array}$ & 22,175 & $75 \%$ & 7,225 & 270 \\
\hline Daily & 3 & $\begin{array}{l}\text { Every } 4 \\
\text { Weeks }\end{array}$ & 519,963 & 523 & $76.8 \%$ & $\begin{array}{l}\$ \\
2,659,125\end{array}$ & 12,633 & $43 \%$ & 16,767 & 159 \\
\hline Daily & 4 & $\begin{array}{l}\text { Every } 4 \\
\text { Weeks }\end{array}$ & 656,447 & 455 & $65.7 \%$ & $\begin{array}{l}\$ \\
3,352,295\end{array}$ & 8,117 & $28 \%$ & 21,283 & 158 \\
\hline Daily & 5 & $\begin{array}{l}\text { Every } 4 \\
\text { Weeks }\end{array}$ & 791,786 & 438 & $56.7 \%$ & $\begin{array}{l}\$ \\
4,041,065\end{array}$ & 5,601 & $19 \%$ & 23,799 & 170 \\
\hline Daily & 6 & $\begin{array}{l}\text { Every } 4 \\
\text { Weeks }\end{array}$ & 926,660 & 442 & $49.4 \%$ & $\begin{array}{l}\$ \\
4,728,030\end{array}$ & 3,951 & $13 \%$ & 25,449 & 186 \\
\hline Daily & 7 & $\begin{array}{l}\text { Every } 4 \\
\text { Weeks }\end{array}$ & $1,061,250$ & 456 & $43.6 \%$ & $\begin{array}{l}\$ \\
5,413,870\end{array}$ & 2,836 & $10 \%$ & 26,564 & 204 \\
\hline Daily & 8 & $\begin{array}{l}\text { Every } 4 \\
\text { Weeks }\end{array}$ & $1,195,639$ & 477 & $39.1 \%$ & $\begin{array}{l}\$ \\
6,098,890\end{array}$ & 2,078 & $7 \%$ & 27,322 & 223 \\
\hline Daily & 9 & $\begin{array}{l}\text { Every } 4 \\
\text { Weeks }\end{array}$ & $1,329,872$ & 504 & $35.6 \%$ & $\begin{array}{l}\$ \\
6,783,260\end{array}$ & 1,568 & $5 \%$ & 27,832 & 244 \\
\hline Daily & 10 & $\begin{array}{l}\text { Every } 4 \\
\text { Weeks }\end{array}$ & $1,463,980$ & 533 & $32.8 \%$ & $\begin{array}{l}\$ \\
7,467,090\end{array}$ & 1,229 & $4 \%$ & 28,171 & 265 \\
\hline Daily & 11 & $\begin{array}{l}\text { Every } 4 \\
\text { Weeks }\end{array}$ & $1,597,982$ & 564 & $30.6 \%$ & $\begin{array}{l}\$ \\
8,150,440\end{array}$ & 1,009 & $3 \%$ & 28,391 & 287 \\
\hline Daily & 12 & $\begin{array}{l}\text { Every } 4 \\
\text { Weeks }\end{array}$ & $1,731,891$ & 597 & $28.8 \%$ & $\begin{array}{l}\$ \\
8,833,365\end{array}$ & 869 & $3 \%$ & 28,531 & 310 \\
\hline Daily & 13 & $\begin{array}{l}\text { Every } 4 \\
\text { Weeks }\end{array}$ & $1,865,717$ & 631 & $27.3 \%$ & $\begin{array}{l}\$ \\
9,515,895\end{array}$ & 784 & $3 \%$ & 28,616 & 333 \\
\hline Daily & 14 & $\begin{array}{l}\text { Every } 4 \\
\text { Weeks }\end{array}$ & $1,999,465$ & 665 & $26.0 \%$ & $\$$ & 736 & $3 \%$ & 28,664 & 356 \\
\hline Daily & 15 & $\begin{array}{l}\text { Every } 4 \\
\text { Weeks }\end{array}$ & $2,133,140$ & 699 & $24.8 \%$ & $\begin{array}{l}\text { \$ } \\
10,879,835\end{array}$ & 713 & $2 \%$ & 28,687 & 379 \\
\hline $\begin{array}{l}\text { Every } 2 \\
\text { Days }\end{array}$ & 1 & $\begin{array}{l}\text { Every } 4 \\
\text { Weeks }\end{array}$ & 147,126 & 1,441 & $97.9 \%$ & $\stackrel{\$}{\$ 779,545}$ & 29,323 & $100 \%$ & 77 & $\$ 10,124$ \\
\hline $\begin{array}{l}\text { Every } 2 \\
\text { Days }\end{array}$ & 2 & $\begin{array}{l}\text { Every } 4 \\
\text { Weeks }\end{array}$ & 223,717 & 1,167 & $95.8 \%$ & $\begin{array}{l}\$ \\
1,166,695\end{array}$ & 28,300 & $96 \%$ & 1,100 & $\$ 1,061$ \\
\hline $\begin{array}{l}\text { Every } 2 \\
\text { Days }\end{array}$ & 3 & $\begin{array}{l}\text { Every } 4 \\
\text { Weeks }\end{array}$ & 297,344 & 833 & $91.8 \%$ & $\begin{array}{l}\$ \\
1,535,370\end{array}$ & 23,878 & $81 \%$ & 5,522 & 278 \\
\hline $\begin{array}{l}\text { Every } 2 \\
\text { Days }\end{array}$ & 4 & $\begin{array}{l}\text { Every } 4 \\
\text { Weeks }\end{array}$ & 366,784 & 589 & $85.3 \%$ & $\begin{array}{l}\$ \\
1,883,135\end{array}$ & 16,959 & $58 \%$ & 12,441 & 151 \\
\hline $\begin{array}{l}\text { Every } 2 \\
\text { Days }\end{array}$ & 5 & $\begin{array}{l}\text { Every } 4 \\
\text { Weeks }\end{array}$ & 433,293 & 454 & $77.2 \%$ & $\begin{array}{l}\$ \\
2,218,215\end{array}$ & 11,022 & $37 \%$ & 18,378 & 121 \\
\hline $\begin{array}{l}\text { Every } 2 \\
\text { Days }\end{array}$ & 6 & $\begin{array}{l}\text { Every } 4 \\
\text { Weeks }\end{array}$ & 498,186 & 389 & $69.2 \%$ & $\begin{array}{l}\$ \\
2,546,870\end{array}$ & 7,139 & $24 \%$ & 22,261 & 114 \\
\hline $\begin{array}{l}\text { Every } 2 \\
\text { Days }\end{array}$ & 7 & $\begin{array}{l}\text { Every } 4 \\
\text { Weeks }\end{array}$ & 562,247 & 362 & $62.4 \%$ & $\begin{array}{l}\$ \\
2,872,335\end{array}$ & 4,806 & $16 \%$ & 24,594 & 117 \\
\hline $\begin{array}{l}\text { Every } 2 \\
\text { Days }\end{array}$ & 8 & $\begin{array}{l}\text { Every } 4 \\
\text { Weeks }\end{array}$ & 625,866 & 354 & $57.1 \%$ & $\begin{array}{l}\$ \\
3,196,110\end{array}$ & 3,411 & $12 \%$ & 25,989 & 123 \\
\hline $\begin{array}{l}\text { Every } 2 \\
\text { Days }\end{array}$ & 9 & $\begin{array}{l}\text { Every } 4 \\
\text { Weeks }\end{array}$ & 689,229 & 357 & $53.0 \%$ & $\begin{array}{l}\$ \\
3,518,885\end{array}$ & 2,560 & $9 \%$ & 26,840 & 131 \\
\hline $\begin{array}{l}\text { Every } 2 \\
\text { Days }\end{array}$ & 10 & $\begin{array}{l}\text { Every } 4 \\
\text { Weeks }\end{array}$ & 752,427 & 366 & $49.8 \%$ & $\begin{array}{l}\$ \\
3,840,995\end{array}$ & 2,030 & $7 \%$ & 27,370 & 140 \\
\hline $\begin{array}{l}\text { Every } 2 \\
\text { Days }\end{array}$ & 11 & $\begin{array}{l}\text { Every } 4 \\
\text { Weeks }\end{array}$ & 815,507 & 379 & $47.3 \%$ & $\begin{array}{l}\$ \\
4,162,610\end{array}$ & 1,699 & $6 \%$ & 27,701 & 150 \\
\hline
\end{tabular}




\begin{tabular}{|c|c|c|c|c|c|c|c|c|c|c|c|}
\hline $\begin{array}{l}\text { Every } 2 \\
\text { Days }\end{array}$ & 12 & $\begin{array}{l}\text { Every } 4 \\
\text { Weeks }\end{array}$ & 878,497 & 393 & $45.3 \%$ & $\begin{array}{l}\$ \\
4,483,830\end{array}$ & 1,493 & $5 \%$ & 27,907 & $\$$ & 161 \\
\hline $\begin{array}{l}\text { Every } 2 \\
\text { Days }\end{array}$ & 13 & $\begin{array}{l}\text { Every } 4 \\
\text { Weeks }\end{array}$ & 941,411 & 409 & $43.5 \%$ & $\begin{array}{l}\$ \\
4,804,710\end{array}$ & 1,368 & $5 \%$ & 28,032 & $\$$ & 171 \\
\hline $\begin{array}{l}\text { Every } 2 \\
\text { Days }\end{array}$ & 14 & $\begin{array}{l}\text { Every } 4 \\
\text { Weeks }\end{array}$ & $1,004,260$ & 425 & $42.0 \%$ & $\begin{array}{l}\$ \\
5,125,285\end{array}$ & 1,298 & $4 \%$ & 28,102 & $\$$ & 182 \\
\hline $\begin{array}{l}\text { Every } 2 \\
\text { Days }\end{array}$ & 15 & $\begin{array}{l}\text { Every } 4 \\
\text { Weeks }\end{array}$ & $1,067,050$ & 442 & $40.6 \%$ & $\begin{array}{l}\$ \\
5,445,580\end{array}$ & 1,264 & $4 \%$ & 28,136 & $\$$ & 194 \\
\hline
\end{tabular}

\begin{tabular}{|c|c|c|c|c|c|c|c|c|c|c|}
\hline $\begin{array}{l}\text { Every } 3 \\
\text { Days }\end{array}$ & 1 & $\begin{array}{l}\text { Every } 4 \\
\text { Weeks }\end{array}$ & 114,368 & 1,553 & $98.5 \%$ & $\begin{array}{l}\$ \\
613,835\end{array}$ & 29,401 & $100 \%$ & undefined & undefined \\
\hline $\begin{array}{l}\text { Every } 3 \\
\text { Days }\end{array}$ & 2 & $\begin{array}{l}\text { Every } 4 \\
\text { Weeks }\end{array}$ & 164,176 & 1,437 & $97.5 \%$ & $\begin{array}{l}\$ \\
867,630\end{array}$ & 29,302 & $100 \%$ & 98 & $\$ 8,853$ \\
\hline $\begin{array}{l}\text { Every } 3 \\
\text { Days }\end{array}$ & 3 & $\begin{array}{l}\text { Every } 4 \\
\text { Weeks }\end{array}$ & 212,825 & 1,249 & $96.2 \%$ & $\begin{array}{l}\$ \\
1,113,725\end{array}$ & 28,694 & $98 \%$ & 706 & \$ 1,578 \\
\hline $\begin{array}{l}\text { Every } 3 \\
\text { Days }\end{array}$ & 4 & $\begin{array}{l}\text { Every } 4 \\
\text { Weeks }\end{array}$ & 259,674 & 1,024 & $94.1 \%$ & $\begin{array}{l}\$ \\
1,348,765\end{array}$ & 26,641 & $91 \%$ & 2,759 & 489 \\
\hline $\begin{array}{l}\text { Every } 3 \\
\text { Days }\end{array}$ & 5 & $\begin{array}{l}\text { Every } 4 \\
\text { Weeks }\end{array}$ & 304,403 & 812 & $91.2 \%$ & $\begin{array}{l}\$ \\
1,572,165\end{array}$ & 22,624 & $77 \%$ & 6,776 & 232 \\
\hline $\begin{array}{l}\text { Every } 3 \\
\text { Days }\end{array}$ & 6 & $\begin{array}{l}\text { Every } 4 \\
\text { Weeks }\end{array}$ & 347,099 & 649 & $87.3 \%$ & $\begin{array}{l}\$ \\
1,785,670\end{array}$ & 17,530 & $60 \%$ & 11,870 & 150 \\
\hline $\begin{array}{l}\text { Every } 3 \\
\text { Days }\end{array}$ & 7 & $\begin{array}{l}\text { Every } 4 \\
\text { Weeks }\end{array}$ & 388,161 & 541 & $82.8 \%$ & $\begin{array}{l}\$ \\
1,991,960\end{array}$ & 12,762 & $43 \%$ & 16,638 & 120 \\
\hline $\begin{array}{l}\text { Every } 3 \\
\text { Days }\end{array}$ & 8 & $\begin{array}{l}\text { Every } 4 \\
\text { Weeks }\end{array}$ & 428,057 & 478 & $78.4 \%$ & $\begin{array}{l}\text { \$ } \\
2,193,415\end{array}$ & 9,090 & $31 \%$ & 20,310 & 108 \\
\hline $\begin{array}{l}\text { Every } 3 \\
\text { Days }\end{array}$ & 9 & $\begin{array}{l}\text { Every } 4 \\
\text { Weeks }\end{array}$ & 467,172 & 446 & $74.6 \%$ & $\begin{array}{l}\$ \\
2,391,730\end{array}$ & 6,579 & $22 \%$ & 22,821 & 105 \\
\hline $\begin{array}{l}\text { Every } 3 \\
\text { Days }\end{array}$ & 10 & $\begin{array}{l}\text { Every } 4 \\
\text { Weeks }\end{array}$ & 505,774 & 433 & $71.6 \%$ & $\begin{array}{l}\$ \\
2,587,980\end{array}$ & 4,977 & $17 \%$ & 24,423 & 106 \\
\hline $\begin{array}{l}\text { Every } 3 \\
\text { Days }\end{array}$ & 11 & $\begin{array}{l}\text { Every } 4 \\
\text { Weeks }\end{array}$ & 544,034 & 433 & $69.4 \%$ & $\begin{array}{l}\$ \\
2,782,835\end{array}$ & 4,001 & $14 \%$ & 25,399 & 110 \\
\hline $\begin{array}{l}\text { Every } 3 \\
\text { Days }\end{array}$ & 12 & $\begin{array}{l}\text { Every } 4 \\
\text { Weeks }\end{array}$ & 582,057 & 438 & $67.6 \%$ & $\begin{array}{l}\text { \$ } \\
2,976,685\end{array}$ & 3,425 & $12 \%$ & 25,975 & 115 \\
\hline $\begin{array}{l}\text { Every } 3 \\
\text { Days }\end{array}$ & 13 & $\begin{array}{l}\text { Every } 4 \\
\text { Weeks }\end{array}$ & 619,909 & 448 & $66.2 \%$ & $\begin{array}{l}\$ \\
3,169,775\end{array}$ & 3,099 & $11 \%$ & 26,301 & 121 \\
\hline $\begin{array}{l}\text { Every } 3 \\
\text { Days }\end{array}$ & 14 & $\begin{array}{l}\text { Every } 4 \\
\text { Weeks }\end{array}$ & 657,628 & 459 & $65.0 \%$ & $\begin{array}{l}\$ \\
3,362,255\end{array}$ & 2,925 & $10 \%$ & 26,475 & 127 \\
\hline $\begin{array}{l}\text { Every } 3 \\
\text { Days }\end{array}$ & 15 & $\begin{array}{l}\text { Every } 4 \\
\text { Weeks }\end{array}$ & 695,240 & 470 & $63.8 \%$ & $\begin{array}{l}\$ \\
3,554,230\end{array}$ & 2,844 & $10 \%$ & 26,556 & 134 \\
\hline
\end{tabular}

a Parameters for this simulation are as follows: initial susceptible population $=29,400$, initial infected population $=600$, testing horizon $=80$ days, cycles per day $=1$, days per week $=5, R_{0}=2.3$, time for virus incubation $=3$ days, time to recovery $=10$ days, asymptomatic advancing to symptoms $=30 \%$, symptom case fatality $=2.0 \%$, test sensitivity $=0.8$, test specificity $=0.98$, exogenous shock $=$ yes, frequency of exogenous shock $=$ every 5 days, new infections per shock $=10$, secondary cadence $=$ yes, new $R_{0}=2.3$ 
Table 3. Comparison of three $R_{0} s$ on testing results of 30,000 people

\begin{tabular}{|c|c|c|c|c|c|c|c|c|c|c|c|}
\hline $\mathrm{R}_{0}$ & $\begin{array}{l}\text { Cadence } \\
\text { of Primary } \\
\text { Testing }\end{array}$ & $\begin{array}{l}\text { Weeks of } \\
\text { Primary } \\
\text { Testing }\end{array}$ & $\begin{array}{l}\text { Cadence of } \\
\text { Secondary } \\
\text { Testing }\end{array}$ & $\begin{array}{l}\text { Total } \\
\text { Persons } \\
\text { Tested }\end{array}$ & $\begin{array}{l}\text { Average } \\
\text { Number in } \\
\text { Quarantine }\end{array}$ & $\begin{array}{l}\text { Average \% } \\
\text { True Positives } \\
\text { in Quarantine }\end{array}$ & $\begin{array}{l}\text { Total } \\
\text { Testing } \\
\text { Cost }\end{array}$ & $\begin{array}{l}\text { Total } \\
\text { Infections }\end{array}$ & $\begin{array}{l}\text { Percent } \\
\text { Infected }\end{array}$ & $\begin{array}{l}\text { Cases } \\
\text { Averted }\end{array}$ & $\begin{array}{l}\text { Cost } \\
\text { per } \\
\text { Case } \\
\text { Averted }\end{array}$ \\
\hline 1.5 & Daily & 1 & $\begin{array}{l}\text { Every } 4 \\
\text { Weeks }\end{array}$ & 251,235 & 327 & $83.2 \%$ & $\begin{array}{l}\$ \\
1,256,175\end{array}$ & 4,399 & $15 \%$ & 25,001 & $\begin{array}{l}\$ \\
50\end{array}$ \\
\hline 1.5 & Daily & 2 & $\begin{array}{l}\text { Every } 4 \\
\text { Weeks }\end{array}$ & 389,579 & 285 & $68.6 \%$ & $\begin{array}{l}\$ \\
1,947,895\end{array}$ & 2,102 & $7 \%$ & 27,298 & $\begin{array}{c}\$ \\
71\end{array}$ \\
\hline 1.5 & Daily & 3 & $\begin{array}{l}\text { Every } 4 \\
\text { Weeks }\end{array}$ & 525,686 & 300 & $58.8 \%$ & $\begin{array}{l}\$ \\
2,628,430\end{array}$ & 1,497 & $5 \%$ & 27,903 & $\begin{array}{c}\$ \\
94\end{array}$ \\
\hline 1.5 & $\begin{array}{l}\text { Every } 2 \\
\text { Days }\end{array}$ & 1 & $\begin{array}{l}\text { Every } 4 \\
\text { Weeks }\end{array}$ & 178,619 & 272 & $85.1 \%$ & $\begin{array}{l}\$ \\
893,095\end{array}$ & 4,408 & $15 \%$ & 24,992 & $\begin{array}{c}\$ \\
36\end{array}$ \\
\hline 1.5 & $\begin{array}{l}\text { Every } 2 \\
\text { Days }\end{array}$ & 2 & $\begin{array}{l}\text { Every } 4 \\
\text { Weeks }\end{array}$ & 245,207 & 236 & $75.8 \%$ & $\begin{array}{l}\$ \\
1,226,035\end{array}$ & 2,866 & $10 \%$ & 26,534 & $\begin{array}{c}\$ \\
46\end{array}$ \\
\hline 1.5 & $\begin{array}{l}\text { Every } 2 \\
\text { Days }\end{array}$ & 3 & $\begin{array}{l}\text { Every } 4 \\
\text { Weeks }\end{array}$ & 310,761 & 224 & $67.2 \%$ & $\begin{array}{l}\$ \\
1,553,805\end{array}$ & 1,987 & $7 \%$ & 27,413 & $\begin{array}{l}\$ \\
57\end{array}$ \\
\hline 1.5 & $\begin{array}{l}\text { Every } 3 \\
\text { Days }\end{array}$ & 1 & $\begin{array}{l}\text { Every } 4 \\
\text { Weeks }\end{array}$ & 150,781 & 369 & $90.7 \%$ & $\stackrel{\$}{753,905}^{\$}$ & 7,291 & $25 \%$ & 22,109 & $\begin{array}{c}\$ \\
34\end{array}$ \\
\hline 1.5 & $\begin{array}{l}\text { Every } 3 \\
\text { Days }\end{array}$ & 2 & $\begin{array}{l}\text { Every } 4 \\
\text { Weeks }\end{array}$ & 194,745 & 291 & $84.3 \%$ & $\begin{array}{l}\$ \\
973,725\end{array}$ & 4,706 & $16 \%$ & 24,694 & $\begin{array}{c}\$ \\
39\end{array}$ \\
\hline 1.5 & $\begin{array}{l}\text { Every } 3 \\
\text { Days }\end{array}$ & 3 & $\begin{array}{l}\text { Every } 4 \\
\text { Weeks }\end{array}$ & 236,990 & 252 & $77.7 \%$ & $\begin{array}{l}\$ \\
1,184,950\end{array}$ & 3,214 & $11 \%$ & 26,186 & $\begin{array}{c}\$ \\
45\end{array}$ \\
\hline 2.3 & Daily & 1 & $\begin{array}{l}\text { Every } 4 \\
\text { Weeks }\end{array}$ & 249,249 & 379 & $85.7 \%$ & $\begin{array}{l}\$ \\
1,246,245\end{array}$ & 5,736 & $20 \%$ & 23,664 & $\begin{array}{c}\$ \\
53\end{array}$ \\
\hline 2.3 & Daily & 2 & $\begin{array}{l}\text { Every } 4 \\
\text { Weeks }\end{array}$ & 387,928 & 310 & $71.3 \%$ & $\begin{array}{l}\$ \\
1,939,640\end{array}$ & 2,653 & $9 \%$ & 26,747 & $\begin{array}{c}\$ \\
73\end{array}$ \\
\hline 2.3 & Daily & 3 & $\begin{array}{l}\text { Every } 4 \\
\text { Weeks }\end{array}$ & 523,487 & 318 & $61.3 \%$ & $\begin{array}{l}\text { \$ } \\
2,617,435\end{array}$ & 1,817 & $6 \%$ & 27,583 & $\begin{array}{c}\$ \\
95\end{array}$ \\
\hline 2.3 & $\begin{array}{l}\text { Every } 2 \\
\text { Days }\end{array}$ & 1 & $\begin{array}{l}\text { Every } 4 \\
\text { Weeks }\end{array}$ & 174,592 & 394 & $90.1 \%$ & $\begin{array}{l}\$ \\
872,960\end{array}$ & 7,449 & $25 \%$ & 21,951 & $\begin{array}{c}\$ \\
40\end{array}$ \\
\hline 2.3 & $\begin{array}{l}\text { Every } 2 \\
\text { Days }\end{array}$ & 2 & $\begin{array}{l}\text { Every } 4 \\
\text { Weeks }\end{array}$ & 241,762 & 336 & $83.3 \%$ & $\begin{array}{l}\$ \\
1,208,810\end{array}$ & 5,161 & $18 \%$ & 24,239 & $\begin{array}{c}\$ \\
50\end{array}$ \\
\hline 2.3 & $\begin{array}{l}\text { Every } 2 \\
\text { Days }\end{array}$ & 3 & $\begin{array}{l}\text { Every } 4 \\
\text { Weeks }\end{array}$ & 307,358 & 305 & $76.2 \%$ & $\begin{array}{l}\$ \\
1,536,790\end{array}$ & 3,643 & $12 \%$ & 25,757 & $\begin{array}{l}\$ \\
60\end{array}$ \\
\hline 2.3 & $\begin{array}{l}\text { Every } 3 \\
\text { Days }\end{array}$ & 3 & $\begin{array}{l}\text { Every } 4 \\
\text { Weeks }\end{array}$ & 230,865 & 428 & $87.3 \%$ & $\begin{array}{l}\$ \\
1,154,325\end{array}$ & 7,225 & $25 \%$ & 22,175 & $\begin{array}{c}\$ \\
52\end{array}$ \\
\hline 2.3 & $\begin{array}{l}\text { Every } 3 \\
\text { Days }\end{array}$ & 4 & $\begin{array}{l}\text { Every } 4 \\
\text { Weeks }\end{array}$ & 271,737 & 406 & $84.1 \%$ & $\begin{array}{l}\$ \\
1,358,685\end{array}$ & 6,023 & $20 \%$ & 23,377 & $\begin{array}{c}\$ \\
58\end{array}$ \\
\hline 2.3 & $\begin{array}{l}\text { Every } 3 \\
\text { Days }\end{array}$ & 5 & $\begin{array}{l}\text { Every } 4 \\
\text { Weeks }\end{array}$ & 311,855 & 394 & $81.1 \%$ & $\begin{array}{l}\$ \\
1,559,275\end{array}$ & 5,117 & $17 \%$ & 24,283 & $\begin{array}{l}\$ \\
64\end{array}$ \\
\hline 3.0 & Daily & 7 & $\begin{array}{l}\text { Every } 4 \\
\text { Weeks }\end{array}$ & $1,054,270$ & 544 & $53.1 \%$ & $\begin{array}{l}\$ \\
5,271,350\end{array}$ & 9,398 & $32 \%$ & 20,002 & $\begin{array}{c}\$ \\
264\end{array}$ \\
\hline 3.0 & Daily & 8 & $\begin{array}{l}\text { Every } 4 \\
\text { Weeks }\end{array}$ & $1,188,067$ & 530 & $45.5 \%$ & $\begin{array}{l}\$ \\
5,940,335\end{array}$ & 5,814 & $20 \%$ & 23,586 & $\begin{array}{c}\$ \\
252\end{array}$ \\
\hline 3.0 & Daily & 9 & $\begin{array}{l}\text { Every } 4 \\
\text { Weeks }\end{array}$ & $1,321,454$ & 538 & $40.1 \%$ & $\begin{array}{l}\$ \\
6,607,270\end{array}$ & 3,630 & $12 \%$ & 25,770 & $\begin{array}{l}\$ \\
256\end{array}$ \\
\hline 3.0 & $\begin{array}{l}\text { Every } 2 \\
\text { Days }\end{array}$ & 10 & $\begin{array}{l}\text { Every } 4 \\
\text { Weeks }\end{array}$ & 734,399 & 525 & $66.0 \%$ & $\begin{array}{l}\$ \\
3,671,995\end{array}$ & 7,341 & $25 \%$ & 22,059 & $\begin{array}{l}\$ \\
166\end{array}$ \\
\hline
\end{tabular}




\begin{tabular}{|c|c|c|c|c|c|c|c|c|c|c|c|}
\hline 3.0 & $\begin{array}{l}\text { Every } 2 \\
\text { Days }\end{array}$ & 11 & $\begin{array}{l}\text { Every } 4 \\
\text { Weeks }\end{array}$ & 795,082 & 517 & $62.5 \%$ & $\begin{array}{l}\text { \$ } \\
3,975,410\end{array}$ & 4,955 & $17 \%$ & 24,445 & $\begin{array}{l}\$ \\
163\end{array}$ \\
\hline 3.0 & $\begin{array}{l}\text { Every } 2 \\
\text { Days }\end{array}$ & 12 & $\begin{array}{l}\text { Every } 4 \\
\text { Weeks }\end{array}$ & 855,403 & 524 & $60.1 \%$ & $\begin{array}{l}\$ \\
4,277,015\end{array}$ & 3,719 & $13 \%$ & 25,681 & $\begin{array}{l}\$ \\
167\end{array}$ \\
\hline 3.0 & $\begin{array}{l}\text { Every } 3 \\
\text { Days }\end{array}$ & 13 & $\begin{array}{l}\text { Every } 4 \\
\text { Weeks }\end{array}$ & 558,825 & 1,117 & $88.1 \%$ & $\begin{array}{l}\$ \\
2,794,125\end{array}$ & 16,790 & $57 \%$ & 12,610 & $\begin{array}{l}\$ \\
222\end{array}$ \\
\hline 3.0 & $\begin{array}{l}\text { Every } 3 \\
\text { Days }\end{array}$ & 14 & $\begin{array}{l}\text { Every } 4 \\
\text { Weeks }\end{array}$ & 586,474 & 1,141 & $87.7 \%$ & $\begin{array}{l}\$ \\
2,932,370\end{array}$ & 14,513 & $49 \%$ & 14,887 & $\begin{array}{l}\$ \\
197\end{array}$ \\
\hline 3.0 & $\begin{array}{l}\text { Every } 3 \\
\text { Days }\end{array}$ & 15 & $\begin{array}{l}\text { Every } 4 \\
\text { Weeks }\end{array}$ & 612,812 & 1,172 & $87.5 \%$ & $\begin{array}{l}\$ \\
3,064,060\end{array}$ & 13,318 & $45 \%$ & 16,082 & $\begin{array}{l}\$ \\
191\end{array}$ \\
\hline
\end{tabular}

a Parameters for this simulation are as follows: initial susceptible population $=29,400$, initial infected population $=600$, testing horizon $=80$ days, cycles per day $=1$, days per week $=5$, time for virus incubation $=3$ days, time to recovery $=10$ days, asymptomatic advancing to symptoms $=30 \%$, symptom case fatality $=2.0 \%$, test sensitivity $=0.8$, test specificity $=0.98$, exogenous shock $=$ yes, frequency of exogenous shock $=$ every 5 days, new infections per shock $=10$, secondary cadence $=$ Yes, new $R_{0}=$ same as primary testing 
Table 4. Influence of different population sizes of testing results ${ }^{a}$

\begin{tabular}{|c|c|c|c|c|c|c|c|c|c|c|c|}
\hline $\begin{array}{l}\text { Numbers } \\
\text { of people }\end{array}$ & $\begin{array}{l}\text { Cadence } \\
\text { of } \\
\text { Primary } \\
\text { Testing }\end{array}$ & $\begin{array}{l}\text { Weeks } \\
\text { of } \\
\text { Primary } \\
\text { Testing }\end{array}$ & $\begin{array}{l}\text { Cadence } \\
\text { of } \\
\text { Secondary } \\
\text { Testing }\end{array}$ & $\begin{array}{l}\text { Total } \\
\text { Persons } \\
\text { Tested }\end{array}$ & $\begin{array}{l}\text { Average } \\
\text { Number in } \\
\text { Quarantine }\end{array}$ & $\begin{array}{l}\text { Average \% } \\
\text { True } \\
\text { Positives } \\
\text { in } \\
\text { Quarantine }\end{array}$ & $\begin{array}{l}\text { Total } \\
\text { testing cost }\end{array}$ & $\begin{array}{l}\text { Total } \\
\text { Infections }\end{array}$ & $\begin{array}{l}\text { Percent } \\
\text { Infected }\end{array}$ & $\begin{array}{l}\text { Cases } \\
\text { Averted }\end{array}$ & $\begin{array}{l}\text { Cost } \\
\text { per } \\
\text { Case } \\
\text { Averted }\end{array}$ \\
\hline \multirow[t]{9}{*}{10,000} & Daily & 6 & $\begin{array}{l}\text { Every } 4 \\
\text { Weeks }\end{array}$ & 307,692 & 188 & $60.7 \%$ & $\begin{array}{l}\$ \\
1,538,460\end{array}$ & 3,212 & $33 \%$ & 6,588 & $\$ 234$ \\
\hline & Daily & 7 & $\begin{array}{l}\text { Every } 4 \\
\text { Weeks }\end{array}$ & 352,520 & 182 & $53.2 \%$ & $\begin{array}{l}\$ 1,762,600 \\
\end{array}$ & 2,336 & $24 \%$ & 7,464 & $\$ 236$ \\
\hline & Daily & 8 & $\begin{array}{l}\text { Every } 4 \\
\text { Weeks }\end{array}$ & 397,164 & 182 & $47.0 \%$ & $\begin{array}{l}\$ \\
1,985,820\end{array}$ & 1,686 & $17 \%$ & 8,114 & $\$ 245$ \\
\hline & $\begin{array}{l}\text { Every } 2 \\
\text { Days }\end{array}$ & 8 & $\begin{array}{l}\text { Every } 4 \\
\text { Weeks }\end{array}$ & 207,460 & 149 & $66.4 \%$ & $\begin{array}{l}\$ \\
1,037,300\end{array}$ & 2,469 & $25 \%$ & 7,331 & \$ 141 \\
\hline & $\begin{array}{l}\text { Every } 2 \\
\text { Days }\end{array}$ & 9 & $\begin{array}{l}\text { Every } 4 \\
\text { Weeks }\end{array}$ & 228,470 & 144 & $61.5 \%$ & $\begin{array}{l}\$ \\
1,142,350\end{array}$ & 1,826 & $19 \%$ & 7,974 & $\$ 143$ \\
\hline & $\begin{array}{l}\text { Every } 2 \\
\text { Days }\end{array}$ & 10 & $\begin{array}{l}\text { Every } 4 \\
\text { Weeks }\end{array}$ & 249,345 & 143 & $57.6 \%$ & $\begin{array}{l}\$ \\
1,246,725\end{array}$ & 1,383 & $14 \%$ & 8,417 & $\$ 148$ \\
\hline & $\begin{array}{l}\text { Every } 3 \\
\text { Days }\end{array}$ & 10 & $\begin{array}{l}\text { Every } 4 \\
\text { Weeks }\end{array}$ & 167,195 & 174 & $76.7 \%$ & $\begin{array}{l}\$ \\
835,975\end{array}$ & 2,645 & $27 \%$ & 7,155 & \$ 117 \\
\hline & $\begin{array}{l}\text { Every } 3 \\
\text { Days }\end{array}$ & 11 & $\begin{array}{l}\text { Every } 4 \\
\text { Weeks }\end{array}$ & 179,739 & 171 & $74.5 \%$ & $\begin{array}{l}\$ \\
898,695\end{array}$ & 2,101 & $21 \%$ & 7,699 & $\$ 117$ \\
\hline & $\begin{array}{l}\text { Every } 3 \\
\text { Days }\end{array}$ & 12 & $\begin{array}{l}\text { Every } 4 \\
\text { Weeks }\end{array}$ & 192,141 & 172 & $72.8 \%$ & $\begin{array}{l}\$ \\
960,705\end{array}$ & 1,747 & $18 \%$ & 8,053 & $\$ 119$ \\
\hline \multirow[t]{9}{*}{100,000} & Daily & 3 & $\begin{array}{l}\text { Every } 4 \\
\text { Weeks }\end{array}$ & $1,740,496$ & 1,372 & $70.3 \%$ & $\begin{array}{l}\$ \\
8,702,480\end{array}$ & 25,339 & $26 \%$ & 72,661 & $\$ 120$ \\
\hline & Daily & 4 & $\begin{array}{l}\text { Every } 4 \\
\text { Weeks }\end{array}$ & $2,194,135$ & 1,217 & $57.1 \%$ & $\begin{array}{l}\$ \\
10,970,675\end{array}$ & 11,742 & $12 \%$ & 86,258 & $\$ 127$ \\
\hline & Daily & 5 & $\begin{array}{l}\text { Every } 4 \\
\text { Weeks }\end{array}$ & $2,644,025$ & 1,252 & $49.3 \%$ & $\begin{array}{l}\$ \\
13,220,125\end{array}$ & 7,460 & $8 \%$ & 90,540 & \$ 146 \\
\hline & $\begin{array}{l}\text { Every } 2 \\
\text { Days }\end{array}$ & 5 & $\begin{array}{l}\text { Every } 4 \\
\text { Weeks }\end{array}$ & $1,449,716$ & 1,255 & $72.3 \%$ & $\begin{array}{l}\$ \\
7,248,580\end{array}$ & 24,812 & $25 \%$ & 73,188 & $\$ 99$ \\
\hline & $\begin{array}{l}\text { Every } 2 \\
\text { Days }\end{array}$ & 6 & $\begin{array}{l}\text { Every } 4 \\
\text { Weeks }\end{array}$ & $1,665,140$ & 1,102 & $63.5 \%$ & $\begin{array}{l}\$ \\
8,325,700\end{array}$ & 13,998 & $14 \%$ & 84,002 & $\$ 99$ \\
\hline & $\begin{array}{l}\text { Every } 2 \\
\text { Days }\end{array}$ & 7 & $\begin{array}{l}\text { Every } 4 \\
\text { Weeks }\end{array}$ & $1,878,233$ & 1,064 & $57.2 \%$ & $\begin{array}{l}\$ \\
9,391,165\end{array}$ & 8,749 & $9 \%$ & 89,251 & \$ 105 \\
\hline & $\begin{array}{l}\text { Every } 3 \\
\text { Days }\end{array}$ & 8 & $\begin{array}{l}\text { Every } 4 \\
\text { Weeks }\end{array}$ & $1,431,095$ & 1,457 & $76.3 \%$ & $\begin{array}{l}\$ \\
7,155,475\end{array}$ & 24,207 & $25 \%$ & 73,793 & $\$ 97$ \\
\hline & $\begin{array}{l}\text { Every } 3 \\
\text { Days }\end{array}$ & 9 & $\begin{array}{l}\text { Every } 4 \\
\text { Weeks }\end{array}$ & $1,561,639$ & 1,375 & $72.5 \%$ & $\begin{array}{l}\$ \\
7,808,195\end{array}$ & 17,089 & $17 \%$ & 80,911 & $\$ 97$ \\
\hline & $\begin{array}{l}\text { Every } 3 \\
\text { Days }\end{array}$ & 10 & $\begin{array}{l}\text { Every } 4 \\
\text { Weeks }\end{array}$ & $1,690,765$ & 1,350 & $69.5 \%$ & $\begin{array}{l}\$ \\
8,453,825\end{array}$ & 12,899 & $13 \%$ & 85,101 & $\$ 99$ \\
\hline \multirow[t]{4}{*}{$1,000,000$} & Daily & 2 & $\begin{array}{l}\text { Every } 4 \\
\text { Weeks }\end{array}$ & $12,740,988$ & 21,216 & $86.4 \%$ & $\begin{array}{l}\$ \\
63,704,940\end{array}$ & 592,616 & $60 \%$ & 387,384 & \$ 164 \\
\hline & Daily & 3 & $\begin{array}{l}\text { Every } 4 \\
\text { Weeks }\end{array}$ & $17,434,893$ & 12,113 & $66.2 \%$ & $\begin{array}{l}\$ \\
87,174,465\end{array}$ & 174,295 & $18 \%$ & 805,705 & $\$ 108$ \\
\hline & Daily & 4 & $\begin{array}{l}\text { Every } 4 \\
\text { Weeks }\end{array}$ & $21,965,460$ & 10,915 & $52.1 \%$ & $\begin{array}{l}\$ \\
109,827,300\end{array}$ & 49,408 & $5 \%$ & 930,592 & $\$ 118$ \\
\hline & $\begin{array}{l}\text { Every } 2 \\
\text { Days }\end{array}$ & 4 & $\begin{array}{l}\text { Every } 4 \\
\text { Weeks }\end{array}$ & $12,317,679$ & 15,198 & $80.8 \%$ & $\begin{array}{l}\$ \\
61,588,395\end{array}$ & 396,023 & $40 \%$ & 583,977 & $\$ 105$ \\
\hline
\end{tabular}




\begin{tabular}{|c|c|c|c|c|c|c|c|c|c|c|}
\hline $\begin{array}{l}\text { Every } 2 \\
\text { Days }\end{array}$ & 5 & $\begin{array}{l}\text { Every } 4 \\
\text { Weeks }\end{array}$ & $14,519,113$ & 11,455 & $69.6 \%$ & $\begin{array}{l}\$ \\
72,595,565\end{array}$ & 195,390 & $20 \%$ & 784,610 & $\$ 93$ \\
\hline $\begin{array}{l}\text { Every } 2 \\
\text { Days }\end{array}$ & 6 & $\begin{array}{l}\text { Every } 4 \\
\text { Weeks }\end{array}$ & $16,669,612$ & 10,207 & $60.6 \%$ & $\begin{array}{l}\$ \\
83,348,060\end{array}$ & 98,525 & $10 \%$ & 881,475 & $\$ 95$ \\
\hline $\begin{array}{l}\text { Every } 3 \\
\text { Days }\end{array}$ & 7 & $\begin{array}{l}\text { Every } 4 \\
\text { Weeks }\end{array}$ & $13,000,213$ & 15,648 & $80.0 \%$ & $\begin{array}{l}\$ \\
65,001,065\end{array}$ & 325,209 & $33 \%$ & 654,791 & $\$ 99$ \\
\hline $\begin{array}{l}\text { Every } 3 \\
\text { Days }\end{array}$ & 8 & $\begin{array}{l}\text { Every } 4 \\
\text { Weeks }\end{array}$ & $14,328,241$ & 13,984 & $75.2 \%$ & $\begin{array}{l}\$ \\
71,641,205\end{array}$ & 216,881 & $22 \%$ & 763,119 & 94 \\
\hline $\begin{array}{l}\text { Every } 3 \\
\text { Days }\end{array}$ & 9 & $\begin{array}{l}\text { Every } 4 \\
\text { Weeks }\end{array}$ & $15,634,333$ & 13,271 & $71.4 \%$ & $\begin{array}{l}\$ \\
78,171,665\end{array}$ & 151,289 & $15 \%$ & 828,711 & $\$ 94$ \\
\hline
\end{tabular}

a Parameters for this simulation are as follows: testing horizon $=80$ days, cycles per day $=1$, days per week $=5, R_{0}=2.3$, time for virus incubation $=3$ days, time to recovery $=10$ days, asymptomatic advancing to symptoms $=30 \%$, symptom case fatality $=2.0 \%$, test sensitivity $=0.8$, test specificity $=0.98$, exogenous shock = yes, frequency of exogenous shock = every 5 days, new infections per shock $=10$, secondary cadence $=$ yes, new $R_{0}=2.3$ 
Table 5. Testing in simulated long-term care centers ${ }^{a}$

\begin{tabular}{|c|c|c|c|c|c|c|c|c|c|c|}
\hline $\begin{array}{l}\text { Cadence of } \\
\text { Primary } \\
\text { Testing }\end{array}$ & $\begin{array}{l}\text { Weeks of } \\
\text { Primary } \\
\text { Testing }\end{array}$ & $\begin{array}{l}\text { Cadence of } \\
\text { Secondary } \\
\text { Testing }\end{array}$ & $\begin{array}{l}\text { Total } \\
\text { Persons } \\
\text { Tested }\end{array}$ & $\begin{array}{l}\text { Average } \\
\text { Number in } \\
\text { Quarantine }\end{array}$ & $\begin{array}{l}\text { Average } \\
\% \text { TP in } \\
\text { Quarantine }\end{array}$ & $\begin{array}{l}\text { Total } \\
\text { Testing } \\
\text { Cost }\end{array}$ & $\begin{array}{l}\text { Total } \\
\text { Infections }\end{array}$ & $\begin{array}{l}\text { Percent } \\
\text { Infected }\end{array}$ & $\begin{array}{l}\text { Cases } \\
\text { Averted }\end{array}$ & $\begin{array}{l}\text { Cost } \\
\text { per } \\
\text { Case } \\
\text { Averted }\end{array}$ \\
\hline Daily & 1 & Weekly & 1,844 & 2 & $78.4 \%$ & $\begin{array}{l}\$ \\
9,445\end{array}$ & 19 & $19 \%$ & 79 & $\begin{array}{l}\$ \\
120\end{array}$ \\
\hline Daily & 2 & Weekly & 2,231 & 2 & $74.4 \%$ & $\begin{array}{l}\$ \\
11,420\end{array}$ & 18 & $18 \%$ & 80 & $\begin{array}{l}\$ \\
143\end{array}$ \\
\hline Daily & 3 & Weekly & 2,612 & 2 & $71.0 \%$ & $\begin{array}{l}\$ \\
13,360\end{array}$ & 18 & $18 \%$ & 80 & $\begin{array}{l}\$ \\
167\end{array}$ \\
\hline Daily & 4 & Weekly & 2,991 & 2 & $68.0 \%$ & $\begin{array}{l}\$ \\
15,295\end{array}$ & 18 & $18 \%$ & 80 & $\begin{array}{l}\$ \\
191\end{array}$ \\
\hline Daily & 5 & Weekly & 3,386 & 2 & $63.1 \%$ & $\begin{array}{l}\$ \\
17,300\end{array}$ & 16 & $16 \%$ & 82 & $\begin{array}{c}\$ \\
211\end{array}$ \\
\hline Daily & 6 & Weekly & 3,763 & 2 & $60.0 \%$ & $\begin{array}{l}\$ \\
19,225\end{array}$ & 15 & $15 \%$ & 83 & $\begin{array}{c}\$ \\
232\end{array}$ \\
\hline Daily & 7 & Weekly & 4,134 & 2 & $57.5 \%$ & $\begin{array}{l}\$ \\
21,120\end{array}$ & 14 & $14 \%$ & 84 & $\begin{array}{l}\$ \\
251\end{array}$ \\
\hline Daily & 8 & Weekly & 4,503 & 2 & $55.3 \%$ & $\begin{array}{l}\$ \\
23,000\end{array}$ & 14 & $14 \%$ & 84 & 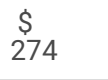 \\
\hline Daily & 9 & Weekly & 4,875 & 3 & $52.6 \%$ & $\begin{array}{l}\$ \\
24,895\end{array}$ & 13 & $13 \%$ & 85 & $\begin{array}{c}\$ \\
293\end{array}$ \\
\hline Daily & 10 & Weekly & 5,243 & 3 & $49.8 \%$ & $\begin{array}{l}\$ \\
26,770\end{array}$ & 12 & $12 \%$ & 86 & $\begin{array}{c}\$ \\
311\end{array}$ \\
\hline Daily & 11 & Weekly & 5,603 & 3 & $47.9 \%$ & $\begin{array}{l}\$ \\
28,610\end{array}$ & 11 & $11 \%$ & 87 & $\begin{array}{c}\$ \\
329\end{array}$ \\
\hline Daily & 12 & Weekly & 5,962 & 3 & $46.3 \%$ & $\begin{array}{l}\$ \\
30,440\end{array}$ & 11 & $11 \%$ & 87 & $\begin{array}{l}\$ \\
350\end{array}$ \\
\hline Daily & 13 & Weekly & 6,321 & 3 & $44.8 \%$ & $\begin{array}{l}\$ \\
32,270\end{array}$ & 11 & $11 \%$ & 87 & $\begin{array}{l}\$ \\
371\end{array}$ \\
\hline Daily & 14 & Weekly & 6,674 & 3 & $44.2 \%$ & $\begin{array}{l}\$ \\
34,070\end{array}$ & 9 & $9 \%$ & 89 & $\begin{array}{c}\$ \\
383\end{array}$ \\
\hline Daily & 15 & Weekly & 7,023 & 3 & $43.2 \%$ & $\begin{array}{l}\$ \\
35,850\end{array}$ & 9 & $9 \%$ & 89 & $\begin{array}{l}\$ \\
403\end{array}$ \\
\hline $\begin{array}{l}\text { Every } 2 \\
\text { Days }\end{array}$ & 1 & Weekly & 1,600 & 2 & $79.0 \%$ & $\begin{array}{l}\$ \\
8,205\end{array}$ & 19 & $19 \%$ & 79 & $\begin{array}{l}\$ \\
104\end{array}$ \\
\hline $\begin{array}{l}\text { Every } 2 \\
\text { Days }\end{array}$ & 2 & Weekly & 1,747 & 2 & $77.2 \%$ & $\begin{array}{l}\$ \\
8,955\end{array}$ & 19 & $19 \%$ & 79 & $\stackrel{\$}{\$ 13}$ \\
\hline $\begin{array}{l}\text { Every } 2 \\
\text { Days }\end{array}$ & 3 & Weekly & 1,893 & 2 & $75.5 \%$ & $\begin{array}{l}\$ \\
9,700\end{array}$ & 18 & $18 \%$ & 80 & $\begin{array}{l}\$ \\
121\end{array}$ \\
\hline $\begin{array}{l}\text { Every } 2 \\
\text { Days }\end{array}$ & 4 & Weekly & 2,036 & 2 & $74.0 \%$ & $\begin{array}{l}\$ \\
10,430\end{array}$ & 18 & $18 \%$ & 80 & $\stackrel{\$}{130}$ \\
\hline $\begin{array}{l}\text { Every } 2 \\
\text { Days }\end{array}$ & 5 & Weekly & 2,185 & 2 & $71.9 \%$ & $\begin{array}{l}\$ \\
11,185\end{array}$ & 18 & $18 \%$ & 80 & $\begin{array}{l}\$ \\
140\end{array}$ \\
\hline $\begin{array}{l}\text { Every } 2 \\
\text { Days }\end{array}$ & 6 & Weekly & 2,335 & 2 & $69.2 \%$ & $\begin{array}{l}\$ \\
11,950\end{array}$ & 16 & $16 \%$ & 82 & $\begin{array}{l}\$ \\
146\end{array}$ \\
\hline $\begin{array}{l}\text { Every } 2 \\
\text { Days }\end{array}$ & 7 & Weekly & 2,477 & 2 & $67.4 \%$ & $\begin{array}{l}\$ \\
12,670\end{array}$ & 16 & $16 \%$ & 82 & $\stackrel{\$}{\$ 55}$ \\
\hline $\begin{array}{l}\text { Every } 2 \\
\text { Days }\end{array}$ & 8 & Weekly & 2,616 & 2 & $66.0 \%$ & $\begin{array}{l}\$ \\
13,380\end{array}$ & 15 & $15 \%$ & 83 & $\begin{array}{l}\$ \\
161\end{array}$ \\
\hline $\begin{array}{l}\text { Every } 2 \\
\text { Days }\end{array}$ & 9 & Weekly & 2,756 & 2 & $64.5 \%$ & $\begin{array}{l}\$ \\
14,095\end{array}$ & 15 & $15 \%$ & 83 & $\begin{array}{l}\$ \\
170\end{array}$ \\
\hline $\begin{array}{l}\text { Every } 2 \\
\text { Days }\end{array}$ & 10 & Weekly & 2,897 & 2 & $62.0 \%$ & $\begin{array}{l}\$ \\
14,810\end{array}$ & 13 & $13 \%$ & 85 & $\begin{array}{l}\$ \\
174\end{array}$ \\
\hline $\begin{array}{l}\text { Every } 2 \\
\text { Days }\end{array}$ & 11 & Weekly & 3,032 & 2 & $60.6 \%$ & $\begin{array}{l}\$ \\
15,500\end{array}$ & 13 & $13 \%$ & 85 & $\begin{array}{l}\$ \\
182\end{array}$ \\
\hline
\end{tabular}




\begin{tabular}{|c|c|c|c|c|c|c|c|c|c|c|}
\hline $\begin{array}{l}\text { Every } 2 \\
\text { Days }\end{array}$ & 12 & Weekly & 3,166 & 2 & $59.5 \%$ & $\begin{array}{l}\$ \\
16,185\end{array}$ & 13 & $13 \%$ & 85 & $\begin{array}{l}\$ \\
190\end{array}$ \\
\hline $\begin{array}{l}\text { Every } 2 \\
\text { Days }\end{array}$ & 13 & Weekly & 3,300 & 2 & $58.4 \%$ & $\begin{array}{l}\$ \\
16,865\end{array}$ & 13 & $13 \%$ & 85 & $\begin{array}{c}\$ \\
198\end{array}$ \\
\hline $\begin{array}{l}\text { Every } 2 \\
\text { Days }\end{array}$ & 14 & Weekly & 3,432 & 2 & $57.8 \%$ & $\begin{array}{l}\$ \\
17,540\end{array}$ & 11 & $11 \%$ & 87 & $\begin{array}{c}\$ \\
202\end{array}$ \\
\hline $\begin{array}{l}\text { Every } 2 \\
\text { Days }\end{array}$ & 15 & Weekly & 3,561 & 2 & $57.1 \%$ & $\begin{array}{l}\$ \\
18,200\end{array}$ & 11 & $11 \%$ & 87 & $\begin{array}{c}\$ \\
209\end{array}$ \\
\hline $\begin{array}{l}\text { Every } 3 \\
\text { Days }\end{array}$ & 1 & Weekly & 1,505 & 2 & $80.7 \%$ & $\begin{array}{l}\$ \\
7,725\end{array}$ & 20 & $20 \%$ & 78 & $\begin{array}{l}\$ \\
99\end{array}$ \\
\hline $\begin{array}{l}\text { Every } 3 \\
\text { Days }\end{array}$ & 2 & Weekly & 1,574 & 2 & $79.6 \%$ & $\begin{array}{l}\$ \\
8,075\end{array}$ & 20 & $20 \%$ & 78 & $\begin{array}{l}\$ \\
104\end{array}$ \\
\hline $\begin{array}{l}\text { Every } 3 \\
\text { Days }\end{array}$ & 3 & Weekly & 1,640 & 2 & $78.7 \%$ & $\begin{array}{l}\$ \\
8,415\end{array}$ & 20 & $20 \%$ & 78 & $\begin{array}{l}\$ \\
108\end{array}$ \\
\hline $\begin{array}{l}\text { Every } 3 \\
\text { Days }\end{array}$ & 4 & Weekly & 1,705 & 2 & $78.0 \%$ & $\begin{array}{l}\$ \\
8,745\end{array}$ & 19 & $19 \%$ & 79 & $\begin{array}{l}\$ \\
111\end{array}$ \\
\hline $\begin{array}{l}\text { Every } 3 \\
\text { Days }\end{array}$ & 5 & Weekly & 1,771 & 2 & $77.0 \%$ & $\begin{array}{l}\$ \\
9,080\end{array}$ & 19 & $19 \%$ & 79 & $\begin{array}{l}\$ \\
115\end{array}$ \\
\hline $\begin{array}{l}\text { Every } 3 \\
\text { Days }\end{array}$ & 6 & Weekly & 1,840 & 2 & $75.6 \%$ & $\begin{array}{l}\$ \\
9,430\end{array}$ & 18 & $18 \%$ & 80 & $\begin{array}{l}\$ \\
118\end{array}$ \\
\hline $\begin{array}{l}\text { Every } 3 \\
\text { Days }\end{array}$ & 7 & Weekly & 1,904 & 2 & $74.6 \%$ & $\begin{array}{l}\$ \\
9,755\end{array}$ & 17 & $17 \%$ & 81 & $\begin{array}{l}\$ \\
120\end{array}$ \\
\hline $\begin{array}{l}\text { Every } 3 \\
\text { Days }\end{array}$ & 8 & Weekly & 1,966 & 2 & $73.8 \%$ & $\begin{array}{l}\$ \\
10,070\end{array}$ & 17 & $17 \%$ & 81 & $\begin{array}{l}\$ \\
124\end{array}$ \\
\hline $\begin{array}{l}\text { Every } 3 \\
\text { Days }\end{array}$ & 9 & Weekly & 2,028 & 2 & $73.0 \%$ & $\begin{array}{l}\$ \\
10,390\end{array}$ & 17 & $17 \%$ & 81 & $\begin{array}{l}\$ \\
128\end{array}$ \\
\hline $\begin{array}{l}\text { Every } 3 \\
\text { Days }\end{array}$ & 10 & Weekly & 2,090 & 2 & $71.8 \%$ & $\begin{array}{l}\$ \\
10,705\end{array}$ & 16 & $16 \%$ & 82 & $\begin{array}{l}\$ \\
131\end{array}$ \\
\hline $\begin{array}{l}\text { Every } 3 \\
\text { Days }\end{array}$ & 11 & Weekly & 2,150 & 2 & $71.0 \%$ & $\begin{array}{l}\$ \\
11,010\end{array}$ & 16 & $16 \%$ & 82 & $\begin{array}{l}\$ \\
134\end{array}$ \\
\hline $\begin{array}{l}\text { Every } 3 \\
\text { Days }\end{array}$ & 12 & Weekly & 2,209 & 2 & $70.3 \%$ & $\begin{array}{l}\$ \\
11,310\end{array}$ & 15 & $15 \%$ & 83 & $\begin{array}{l}\$ \\
136\end{array}$ \\
\hline $\begin{array}{l}\text { Every } 3 \\
\text { Days }\end{array}$ & 13 & Weekly & 2,267 & 2 & $69.8 \%$ & $\begin{array}{l}\$ \\
11,605\end{array}$ & 15 & $15 \%$ & 83 & $\begin{array}{l}\$ \\
140\end{array}$ \\
\hline $\begin{array}{l}\text { Every } 3 \\
\text { Days }\end{array}$ & 14 & Weekly & 2,324 & 2 & $69.4 \%$ & $\begin{array}{l}\$ \\
11,895\end{array}$ & 15 & $15 \%$ & 83 & $\begin{array}{l}\$ \\
143\end{array}$ \\
\hline $\begin{array}{l}\text { Every } 3 \\
\text { Days }\end{array}$ & 15 & Weekly & 2,380 & 2 & $69.0 \%$ & $\begin{array}{l}\$ \\
12,180\end{array}$ & 14 & $14 \%$ & 84 & $\begin{array}{l}\$ \\
145\end{array}$ \\
\hline
\end{tabular}

a Parameters for this simulation are as follows: initial susceptible population $=98$, initial infected population $=2$, testing horizon $=80$ days, cycles per day $=1$, days per week $=5, R_{0}=1.5$, time for virus incubation $=3$ days, time to recovery $=10$ days, asymptomatic advancing to symptoms $=30 \%$, symptom case fatality $=8.0 \%$, test sensitivity $=0.8$, test specificity $=0.98$, exogenous shock $=$ yes, frequency of exogenous shock $=$ every 21 days, new infections per shock $=2$, secondary cadence $=$ yes, new $R_{0}=1.5$ 